\title{
Influence of Niobium and Molybdenum on Mechanical Strength and Wear Resistance of Microalloyed Steels
}

\author{
André Itman Filho ${ }^{a}$, Rosana Vilarim da Silva ${ }^{b}$, Pedro Gabriel Bonella de Oliveira ${ }^{a}$, João Batista \\ Ribeiro Martins ${ }^{c}$, Waldek Wladimir Bose Filho ${ }^{d}$, Martin Strangwood ${ }^{e}$ \\ ${ }^{a}$ Master Program in Metallurgic and Materials Engineering (PROPEMM), Federal Institute of \\ Education, Science and Technology of Espirito Santo, Vitória, ES, Brazil \\ ${ }^{b}$ MasterProgram in Sustainable Technologies (PPGTECS), Federal Institute of Education, Science and \\ Technology of Espirito Santo, Vitória, ES, Brazil \\ ${ }^{c}$ ArcelorMittal Tubarão, Serra, ES, Brasil \\ ${ }^{d}$ Materials Department, São Carlos Engineering School, EEUSP, São Carlos, SP, Brasil \\ ${ }^{e}$ School of Metallurgy and Materials, University of Birmingham, Edgbaston, Birmingham, England
}

Received: December 19, 2016; Revised: April 02, 2017; Accepted: May 21, 2017

The HSLA (High-Strength Low Alloy) steels are used in the production of pipes, flanges and connectors to build ducts for ore, oil and gas transport. The conventional processes are the rolling or forging. In the transport of ore and heavy oil, the abrasive particles impair the surfaces and reduce the pipelines lifetime. Therefore, besides the mechanical properties as API 5L, it is important to verify the wear resistance of these steels. In this context, two microalloyed steels were forged in the form of square bars. Thereafter, specimens of these bars were annealed at $930{ }^{\circ} \mathrm{C}$, quenched at $900{ }^{\circ} \mathrm{C}$ and tempered at $600{ }^{\circ} \mathrm{C}$. Tensile and wear tests were performed. The results show that molybdenum and niobium present similar effects on phase transformation of steels, promoting a desired acicular ferrite/bainite microstructure and fulfill the mechanical strength of API 5L-X70 standard. The molybdenum has dominating effect in the hardenability when in solid solution, however, after tempering, thermodynamic simulation by FactSage software indicates that niobium probably promotes secondary hardening.

Keywords: Steels containing niobium and molybdenum, Heat treatments, Mechanical strength of microalloyed steels, Wear tests of microalloyed steels, FactSage software

\section{Introduction}

API (American Petroleum Institute) steels are used on a large scale, mainly in the construction of pipelines and accessories to transport oil and natural gas. These pipelines operate at great depths and withstand pressures up to $350 \mathrm{bar}$ in the presence of chlorides, sulfides and other dissolved ions ${ }^{1}$. API steels are also used in the ore transportation; however, the inner walls of the pipes have low wear resistance, when in contact with slurries and abrasive particles ${ }^{2,3}$.

The conventional processing of API steels by rolling and forging allow a wide range of thicknesses with control of temperature and plastic deformation during the mechanical forming stages ${ }^{4}$. In forged materials, quenching and tempering heat treatments are necessary to achieve the required mechanical properties.

The grain refining associated to the precipitation hardening by carbides, nitrides and carbonitrides finely dispersed in the matrix are used to increase the mechanical properties. These microalloyed steels usually contain niobium, titanium and vanadium, which ensure good toughness and high tensile strength ${ }^{5,6}$. Additionally, the heat treatment control

*e-mail: andrei@ifes.edu.br of microalloyed steels forgings leads to the formation of non-polygonal or acicular ferrite as well as bainite, which further contribute to strengthening?.

Another chemical element used in these steels is the molybdenum that favors the generation of bainite at relatively low cooling rates and promotes a finer microstructure ${ }^{8,9}$. Molybdenum, together with chromium, plays a unique and important role both by having a marked decreasing effect on the austenite transformation temperature and by forming various carbides with complex constitutions in the steels ${ }^{10}$. Studies have shown that chromium and molybdenum introduce different stoichiometry of carbides according to the chemical composition of the steels ${ }^{11}$. Therefore, in industrial process, adding some molybdenum is a good choice to meet the requirement of strength. The refinement of austenite grains, the microstructure with grain boundary allotriomorphic ferrite, granular bainite and a uniformly dispersion of precipitates in the steel matrix are key aspects in the improvement of mechanical properties, hardness and wear resistance ${ }^{9,12}$. It has been asserted that HSLA steels containing niobium and molybdenum produce a acicular ferritic/bainitic structure with excellent strength-retention characteristics at high temperatures in the range of 600 to 
$700{ }^{\circ} \mathrm{C}$, in comparison to conventional HSLA steels containing niobium and vanadium ${ }^{11,13}$.

The equipment and tools produced with microalloyed steels forgings are commonly subjected to abrasion by soil, sand, ore powder and so on during service ${ }^{4}$. The wear is mainly controlled by the microscopic stress distribution and microstructure in the contact region ${ }^{12}$. The utilization of proper materials and suitable heat treatment can enhance the wear resistance under the low stress abrasion and improve the service life of the relevant machinery.

Therefore, the present research aims to investigate the hardness, mechanical strength, wear coefficient and corresponding microstructures of microalloyed steels with different levels of niobium and molybdenum after quenching and tempering. In order to understand the effects of carbide precipitation in controlling the grain size, thermodynamic simulations with FactSage software were carried out to analyze the type and solubility temperatures of the precipitates formed in these steels.

\section{Experimental Procedures}

Two steels were manufactured in an induction furnace with a capacity of $200 \mathrm{~kg}$. The liquid metal was poured into an ingot mold of cast iron with approximate size of $85 \times 85 \times 800$ $\mathrm{mm}$. The cast ingot was heated at $1050{ }^{\circ} \mathrm{C}$ for two hours and forged in the form of square bars with $38 \mathrm{~mm}$ side. Two samples were obtained and analyzed in an optical emission spectrometer to determinate the chemical composition. The forged bars were heated at $930^{\circ} \mathrm{C}$ and cooled inside the furnace to homogenize the microstructure. Cubic specimens with side $15 \mathrm{~mm}$ and samples in longitudinal orientation with $15 \times 15 \times 100 \mathrm{~mm}$, were cut and machined according to ASTM $\mathrm{E} 8 / \mathrm{E} 8 \mathrm{M}$ to be used in the tensile tests. All specimens were heated at $900{ }^{\circ} \mathrm{C}$ for 30 minutes and cooled in water. Then, they were tempered at $600{ }^{\circ} \mathrm{C}$ for 50 minutes, in order to obtain the maximum contribution by the fine precipitation of carbides in ferrite and to increase the hardenability and the tensile properties ${ }^{14}$. The cooling was done in air.

After quenching and tempering, the cubic samples were prepared according to conventional metallographic methods. For etching, 2\% Nital and Lepera were used, with an application time of approximately 30 seconds. The average of five hardness measurements was obtained with a load of $100 \mathrm{kgf}$ using a Rockwell B hardness tester. The microstructures were characterized by Confocal Optical Microscopy (COM) and backscatter electron images (BSE) in a Scanning Electron Microscope (SEM).

The tensile test was carried out according to ASTM E8-00 in an Emic DL1000 universal test machine, load cell of $10000 \mathrm{kgf}$ and $50 \mathrm{~mm}$ strain gauge with measurable deformation of $25 \mathrm{~mm}$. Five specimens in each condition were pulled with $1 \mathrm{~mm}$ per minute constant strain rate.
The wear coefficients were determined by micro-wear tests using a fixed ball machine and silicon carbide ( $\mathrm{SiC}$ ) as abrasive slurry, with particles size of approximately 5 $\mu \mathrm{m}$ and a concentration of $0,75 \mathrm{~g} / \mathrm{cm}^{3}(75 \mathrm{~g} \mathrm{SiC}$ in $100 \mathrm{ml}$ distilled water) with rotation of the motor shaft of $150 \mathrm{rpm}$. The slurry was dripped on the ball surface at a flow-rate of approximately 1 drop per $3 \mathrm{~s}$. The normal load (FN), which was measured by a cell with an accuracy of $\pm 0.005 \mathrm{~N}$, was $0.24 \pm 0.01 \mathrm{~N}$. Consecutive wear craters were obtained, only one sample for each condition, with test times of 5 to $55 \mathrm{~min}^{15}$. Five measures of the craters diameters were obtained in each interval of five minutes. For each sliding distance $(\mathrm{L})$, the microabrasive wear coefficient $(\mathrm{K})$ was determined when the permanent wear regime was reached using the following Equation $1^{16}$.

$$
K=\frac{\mathrm{V}}{\mathrm{L} \cdot \mathrm{Fn}}
$$

Where Fn is the normal load on the surface of the testing ball and V, calculated by the Equation 2, is the worn volume of material.

$$
V \cong \frac{\pi \cdot b^{4}}{32 \phi}
$$

These values were used to make the graph of wear coefficients. This allows for superior reliability to $95 \%{ }^{17}$.

Thermodynamic modeling was carried out with the FactSage 7.0 software that is a fully integrated computational system that can access thermodynamic data from different compounds, liquid metallic solutions and others ${ }^{18}$. The simulation calculating of the weight and solubilization temperatures of the nitrides, carbides and sulfides present in the alloys were done with chemical compositions of the steels.

\section{Results and Discussion}

The chemical compositions of the microalloyed steels are presented in Table 1.

The chemical compositions in Table 1 reveal that the steels are similar, despite the different levels of niobium and molybdenum. The area reduction of about $80 \%$ in the forging followed by annealing at $930^{\circ} \mathrm{C}$ was sufficient to homogenize the microstructure and the hardness of the bars.

Table 2 presents the average values of hardness measurements obtained from five different regions of each sample, after annealed (A), quenching (Q) and quenching plus tempering with air cooling $(\mathrm{Q}+\mathrm{T})$.

In Table 2 a hardness of $52 \mathrm{HRB}$ is the same in the different sections after annealing. Niobium content influences the grain size, but this mechanism is not able to increase the hardness of the steels after annealed. After quenching, 
Table 1. Chemical compositions of microalloyed steels (\% in weight).

\begin{tabular}{cccccccccccccc}
\hline Steel & $\mathrm{C}$ & $\mathrm{Si}$ & $\mathrm{Mn}$ & $\mathrm{P}$ & $\mathrm{S}$ & $\mathrm{Cr}$ & $\mathrm{Ni}$ & $\mathrm{Mo}$ & $\mathrm{Nb}$ & $\mathrm{Ti}$ & $\mathrm{V}$ & $\mathrm{N}(\mathrm{ppm})$ \\
\hline $0.08 \mathrm{Nb}$ & 0.11 & 0.09 & 0.33 & 0.03 & 0.02 & 0.37 & 0.41 & 0.05 & 0.08 & 0.01 & 0.01 & 72 \\
$0.01 \mathrm{Nb}$ & 0.09 & 0.09 & 0.42 & 0.03 & 0.01 & 0.29 & 0.40 & 0.16 & 0.01 & 0.02 & 0.01 & 52 \\
\hline
\end{tabular}

Table 2. Rockwell B hardness values after annealed at $930^{\circ} \mathrm{C}(\mathrm{A})$, quenching at $900{ }^{\circ} \mathrm{C}(\mathrm{Q})$ and quenching at $900^{\circ} \mathrm{C}$ plus tempering at $600^{\circ} \mathrm{C}(\mathrm{Q}+\mathrm{T})$.

\begin{tabular}{cccc}
\hline Steels & A & Q & Q+T \\
\hline $0.08 \mathrm{Nb}$ & $52 \pm 2$ & $84 \pm 2$ & $82 \pm 1$ \\
$0.01 \mathrm{Nb}$ & $52 \pm 1$ & $105 \pm 2$ & $97 \pm 2$ \\
\hline
\end{tabular}

there was an increase in hardness, due to the presence of displacive constituents in steels, mainly acicular ferrite, bainite and the martensite/austenite microconstituent (MA). In this case, the hardness values of steel containing 0.16 molybdenum is greater than the 0.05 one. This suggests that the hardenability effect of molybdenum is dominating, because it has a beneficial effect when the cooling rate is high and promotes the constituents formation, with high density of dislocations ${ }^{9,10}$. The reduction of hardness after tempering at $600{ }^{\circ} \mathrm{C}$ may be justified by a probable formation of ferrite and cementite from MA.

Regarding the mechanical properties, Table 3 presents the average values and the standard deviations from five tests after each heat treatment.

According to the tensile tests in Table 3, after tempering at $600{ }^{\circ} \mathrm{C}$, the values of the forged steels are consistent with the standard API 5L-X70 ${ }^{19}$. In both steels, the elongation results are in accordance with the standard, different from quenching at $900{ }^{\circ} \mathrm{C}$, where the values are reduced by the presence of MA. Because the higher content of molybdenum in steel containing $0.01 \mathrm{Nb}$, the delay of the ferrite formation promotes a more regular acicular ferrite with lower bainitic microstructure that increases the tensile strength ${ }^{8,9}$. Therefore, it is important to control the heat treatment for achieving the suitable microstructure and mechanical properties of the microalloyed steels for use in the petrochemical industry.

With relation to the wear coefficients in Figure 1a, the values as calculated by the Equation 1, decrease with time and approach the steady state after 50 minutes. In this case $\mathrm{Nb} 0.01$ steel presents a wear coefficient slightly higher than steel containing $0.08 \mathrm{Nb}$, after quenching. However, after quenching plus tempering, is slightly lower. These

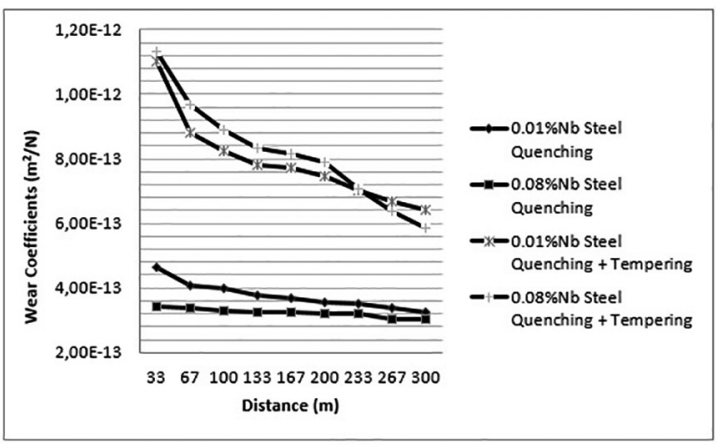

(a)

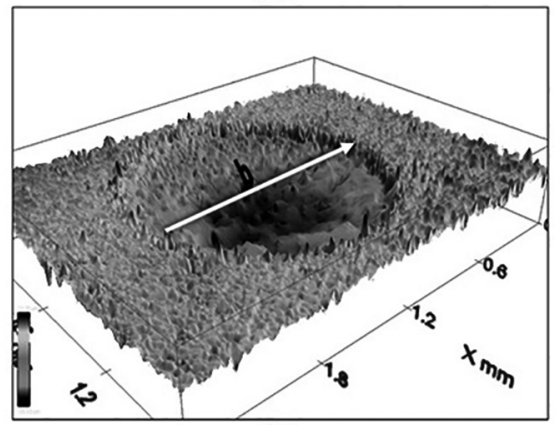

(b)

Figure 1. Wear coefficients of steels after quenching at $900^{\circ} \mathrm{C}$ and quenching at $900{ }^{\circ} \mathrm{C}$ plus tempering at $600{ }^{\circ} \mathrm{C}$ (a) and wear crater in the specimen surface of the steel (b). The arrow indicates the crater size after the test (COM).

results reinforce the hypothesis of a large amount of $\mathrm{Cr}_{23} \mathrm{C}_{6}$ and $\mathrm{Mo}_{23} \mathrm{C}_{6}$ carbides in $0.01 \mathrm{Nb}$ steel, after tempering, as shown in the thermodynamic simulation. In Figure $1 \mathrm{~b}$ it can be noted the scar after touching the steel ball on the specimen surface.

Figures $2 \mathrm{a}$ and $2 \mathrm{~b}$ present the microstructures of microalloyed steels after annealing at $930^{\circ} \mathrm{C}$ with cooling in the furnace, in which a matrix of polygonal ferrite and islands of perlite compose the structures. In this paper the microstructural classification was made according to the definition by Araki and colleagues ${ }^{20}$ and Krauss and Thompson ${ }^{21}$.

Table 3. Yield strength $\left(\sigma_{\mathrm{e}}\right)$, tensile strength $\left(\sigma_{\max }\right)$ and elongation of steels after quenching at $900{ }^{\circ} \mathrm{C}(\mathrm{Q})$ and quenching at $900{ }^{\circ} \mathrm{C}$ plus tempering at $600{ }^{\circ} \mathrm{C}(\mathrm{Q}+\mathrm{T})$.

\begin{tabular}{ccccc}
\hline Steels & Heat Treatment & $\sigma_{\mathrm{e}}(\mathrm{MPa})$ & $\sigma_{\max }(\mathrm{MPa})$ & Elongation $(\%)$ \\
\hline $0.08 \mathrm{Nb}$ & $\mathrm{Q}$ & $630 \pm 11$ & $885 \pm 10$ & $9.0 \pm 1.5$ \\
$0.08 \mathrm{Nb}$ & $\mathrm{Q}+\mathrm{T}$ & $472 \pm 13$ & $535 \pm 15$ & $18.0 \pm 1.0$ \\
$0.01 \mathrm{Nb}$ & $\mathrm{Q}$ & $670 \pm 08$ & $935 \pm 10$ & $9.3 \pm 0.6$ \\
$0.01 \mathrm{Nb}$ & $\mathrm{Q}+\mathrm{T}$ & $526 \pm 05$ & $598 \pm 06$ & $16.0 \pm 0.7$ \\
\hline
\end{tabular}




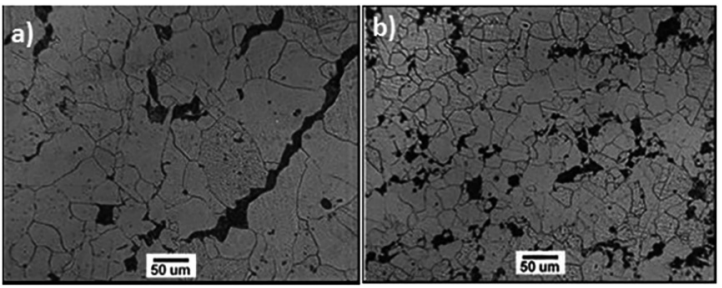

Figure 2. The figures show the microstructures of the annealed steels containing 0.01 (a) and $0.08 \mathrm{Nb}$ (b). In the second, the grains are smaller because the higher niobium content (Nital 2\% - COM).

Figures $3 \mathrm{a}$ and $3 \mathrm{~b}$ present the microstructures of quenched and quenched plus tempering with cooling in air of microalloyed steel containing $0.08 \%$ niobium. In the first, acicular ferrite (AF), bainite (B) and martensite/austenite (MA) white islands appear inner the grain from the rapid water cooling. In the second, it can be noted grain boundary allotriomorphic ferrite (GBA) plus bainite, represented by the sheaves of ferrite parallel with discontinuous carbides ${ }^{22}$. The acicular constituents increase the yield and tensile strength of the material. The disposition of the ferrite plates in different orientations is responsible for the difficulty of crack propagation in the material ${ }^{23}$

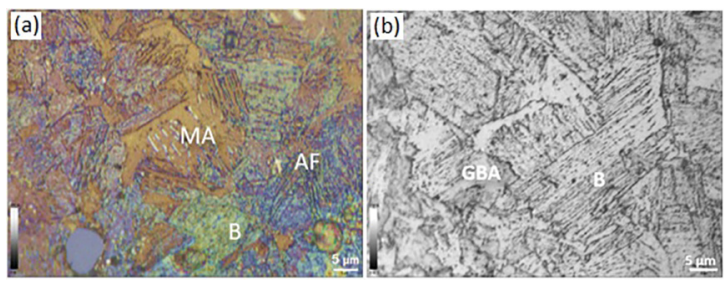

Figure 3. $0.08 \mathrm{Nb}$ steel: the first shows the microstructure after quenched at $900{ }^{\circ} \mathrm{C}$ (Lepera - COM). The second shows the microstructure after quenched at $900{ }^{\circ} \mathrm{C}$ and tempered at $600{ }^{\circ} \mathrm{C}$ (Nital 2\% - COM).

Figures $4 \mathrm{a}$ and $4 \mathrm{~b}$ present the microstructures of quenched and quenched plus tempering with cooling in air of microalloyed steel containing $0.01 \%$ niobium. In the first, after quenching, the microstructure is mostly composed of grain boundary alotriomorphic ferrite (GBA), Widmanstatten ferrite (WF), acicular ferrite (AF) and bainite (B) ${ }^{12,22}$. After tempering in Figure $4 \mathrm{~b}$, it is possible to observe the acicular ferrite and bainite and in this case, the needles of ferrite grow in different directions.

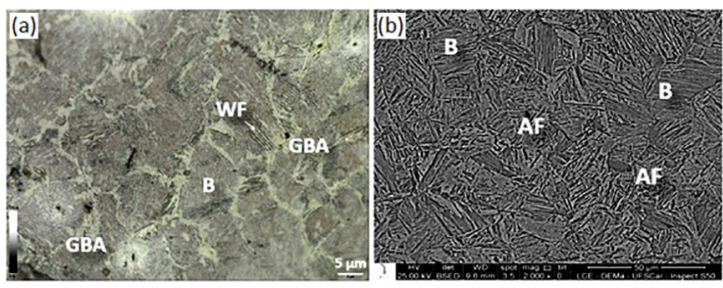

Figure 4. $0.01 \mathrm{Nb}$ steel: the first shows the microstructure after quenched at $900{ }^{\circ} \mathrm{C}$ (Nital 2\% - COM). The second shows the microstructure after quenched at $900{ }^{\circ} \mathrm{C}$ and tempered at $600{ }^{\circ} \mathrm{C}$ (Nital 2\% - MEV).
Despite Figure 4a does not show the MA phase, this constituent was also observed in lower amount in this steel. With relation to the tempering at $600^{\circ} \mathrm{C}$ in Figures $3 \mathrm{~b}$ and $4 \mathrm{~b}$, MA phase disappears in both steels. Thus, there is an increasing elongation with yield strength and tensile strength reduction. In this condition, it is possible to form ferrite and cementite from retained austenite and martensite by a reconstructive mechanism, which may justify the decrease in hardness after this treatment as shown in Table 2. Moreover, accelerated cooling in the steels containing niobium and molybdenum, favor the formation of non-polygonal or acicular ferrite as well as bainite, which further contribute to strengthening ${ }^{9,22}$.

In both steels the microstructures indicate the presence of grain boundary allotriomorphic ferrite. The presence of thin layers of this constituent reduces the austenite grain surfaces, as potential nucleation sites for bainite, and favors the microstructural transformation from bainite to acicular ferrite ${ }^{24}$.

The amounts of the precipitates shown in Figures 5a and $5 \mathrm{~b}$ were predicted by the FactSage software and the results are used just as indicators to the patterns in these steels. According to deviations from the equilibrium conditions, the FactSage can't be employed for precipitates forming during the continuous cooling. These simulations are made considering the most thermodynamically probable products and the values need to be confirmed by another technique, such as transmission electronic microscopy (TEM).
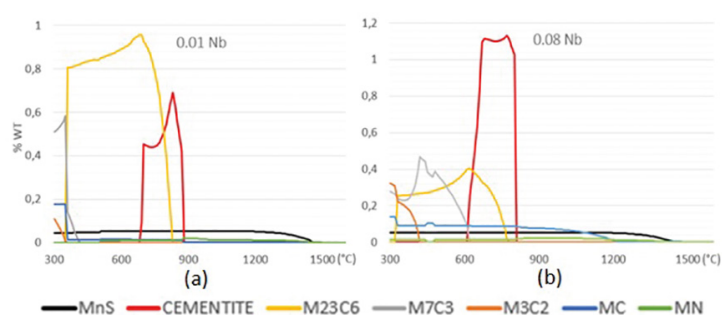

Figure 5. Thermodynamic simulation performed on 0.01 (a) and 0.08 (b) niobium steels.

It can be noted the presence of cementite, $\mathrm{MC}, \mathrm{M}_{7} \mathrm{C}_{3}$ and $\mathrm{M}_{23} \mathrm{C}_{6}$ carbides, mainly of chrome and molybdenum, and at higher temperatures, niobium and titanium carbides and nitrides and manganese sulfide.

In microalloyed steels, niobium, vanadium and titanium, even with levels lower than $0.15 \%$, promote the formation of carbides finely dispersed in the matrix, during the austenite/ ferrite transformation ${ }^{25}$. As in the literature, simulation results indicate the presence of carbides and nitrides of niobium and titanium. The formation of these precipitates in forging can be responsible for the slightly smaller grain size in the $0.08 \mathrm{Nb}$ steel (Figure 2.b). The simulation also indicates the formation of $\mathrm{M}_{7} \mathrm{C}_{3}$ and $\mathrm{M}_{23} \mathrm{C}_{6}$ chromium carbides and $\mathrm{MC}$ and $\mathrm{M}_{23} \mathrm{C}_{6}$ molybdenum carbides in the range of 300 to 
$800{ }^{\circ} \mathrm{C}$. Moreover, literature results indicate that molybdenum contents lower than $0.5 \%$ is ineffective in the secondary hardening phenomena, it is possible that the relative higher amount of precipitation in $0.01 \mathrm{Nb}$ steel, mainly $\mathrm{Cr}_{23} \mathrm{C}_{6}$ and $\mathrm{Mo}_{23} \mathrm{C}_{6}$, can justify the value shown in Figure $1 \mathrm{a}^{26}$.

The thermodynamic simulations also indicate the probable precipitation of $\mathrm{NbC}$ for the $0.08 \mathrm{Nb}$ steel at the tempering temperature. Figures $6 \mathrm{a}$ and $6 \mathrm{~b}$ show the MX type precipitation in both steels. It is known that MX type precipitates promotes a finely dispersed precipitation in the matrix and contributes to wear resistance ${ }^{27}$.

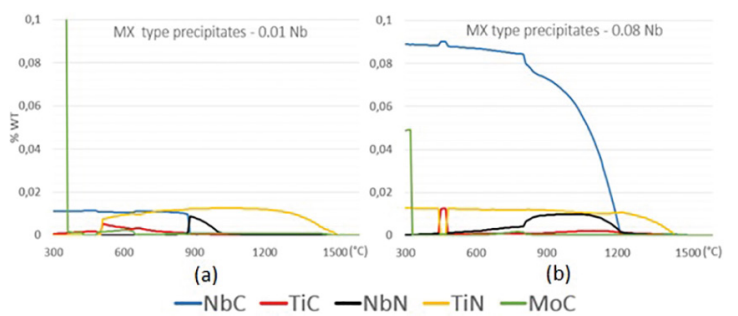

Figure 6. MX type simulation on 0.01 (a) and 0.08 (b) niobium steels.

Regarding the wear resistance after quenching, steels with similar type of microstructure show a linear decrease in weight loss with decreasing grain size ${ }^{28}$. So, it is possible that higher amount of niobium is responsible for grain refining and the better wear performance in $0.08 \mathrm{Nb}$ steel after quenching.

With relation to yield and tensile strength, the microstructural analysis of other samples after quenching and quenching plus tempering conditions, reveals a higher amount of acicular ferrite and bainite in $0.01 \mathrm{Nb}$ steel. According to the literature, this combination is the most indicated in the mechanical strength of microalloyed steels. It is possible that the higher molybdenum content is responsible for this result ${ }^{9,13}$.

\section{Conclusions}

The results of this research show that:

- The steels microstructures with acicular ferrite and bainite after quenching and tempering are suitable to meet the values of standard API 5L-X70;

- According to the wear coefficients and simulation, the higher amount of niobium in $0.08 \mathrm{Nb}$ steel promotes grain refining which appears to lead to a better wear performance after quenching;

- Regarding the microstructure, molybdenum can be replaced by niobium, because identical microstructure can be obtained using adequate heat treatments;

- Molybdenum is responsible for a greater amount of acicular and bainite ferrite in $0.01 \mathrm{Nb}$ steel;

- Acicular ferrite associated with bainite is indicated to a better performance in mechanical strength of microalloyed steels;
- It is possible control the heat treatment for achieving the suitable microstructure and mechanical properties of the microalloyed steels for use in petrochemical industry.

\section{Acknowledgement}

The authors thank Grupo Metal for the samples and FAPES for the financial support.

\section{References}

1. Gray MJ, Siciliano F. High Strength Microalloyed Linepipe: Half a Century of Evolution. In: Pipeline Technology Conference; 2009 Oct 12-14; Ostende, Belgium.

2. Kalwa C, Hillenbrand HG, Gräf M. High strength steel pipes - new developments and applications. In: Proceedings of Onshore Pipeline Conference; 2002 Jun 10-11; Dallas, TX, USA. Ratingen: EUROPIPE; 2002.

3. Godefroid LB, Cândido LC, Toffolo RVB, Barbosa LHS. Microstructure and mechanical properties of two API steels for iron ore pipelines. Materials Research. 2014;17(Suppl. 1):114-120.

4. Hillenbrand HG, Kalwa C. High strength line pipe for project cost reduction. World Pipelines. 2002;2(1):1-10.

5. Hulka K. Sour Gas Resistant Steel. Niobium Information. $2001 ; 18(1)$

6. Li L, Xu L. Designing with High-Strength Low-Alloy Steels. In: Totten GE, Xie L, Funatani K, eds. Handbook of Mechanical Alloy Design. New York: Marcel Dekker; 2004. p. 249-320.

7. Fatehi A, Calvo J, Elwazri AM, Yue S. Strengthening of HSLA steels by cool deformation. Materials Science and Engineering: $A$. 2010;527(16-17):4233-4240. DOI: 10.1016/j.msea.2010.03.036

8. Mohrbacher H. Synergies of Niobium and Boron Microalloying in Molybdenum Based Bainitic and Martensitic Steels. In: Mohrbacher H, ed. Fundamentals and Applications of Mo and Nb Alloying in High Performance Steels. Volume 1. Pittsburgh: CBMM, IMOA and TMS. 2014; p. 83-108.

9. Shang CJ, Miao CL, Subramanian, SV. Austenite Processing and Phase Transformation of Niobium and Molybdenum Alloyed High Performance Structural Steel. In: Mohrbacher $\mathrm{H}$, ed. Fundamentals and Applications of Mo and Nb Alloying in High Performance Steels. Volume 1. Pittsburgh: CBMM, IMOA and TMS. 2014. p. 37-61.

10. Lee WB, Hong SG, Park CG, Park SH. Carbide precipitation and high-temperature strength of hot-rolled high-strength, low-alloy steels containing $\mathrm{Nb}$ and Mo. Metallurgical and Materials Transactions A. 2002;33:1689-1698.

11. Kuo K. Carbides in chromium, molybdenum and tungsten steels. Journal of the Iron and Steel Institute. 1953;173:363-375.

12. Xu P, Bai B, Yin F, Fang H, Nagai K. Microstructure control and wear resistance of grain boundary allotriomorphic ferrite/ granular bainite duplex steel. Materials Science and Engineering: A. 2004;385(1-2):65-73. 
13. Huang BM, Yang JR, Huang CY. The Synergistic Effect of Niobium-Molybdenum Additions on the Microstructure of LowCarbon Bainitic Steel. In: Mohrbacher H, ed. Fundamentals and Applications of Mo and Nb Alloying in High Performance Steels. Volume 2. Pittsburgh: CBMM, IMOA and TMS. 2015; p. 29-50.

14. Altuna MA, Iza-Mendia A, Gutierrez I. Precipitation of $\mathrm{Nb}$ in Ferrite After Austenite Conditioning. Part II: Strengthening Contribution in High-Strength Low-Alloy (HSLA) Steels. Metallurgical and Materials Transactions A. 2012;43(12):45714586. DOI: $10.1007 / \mathrm{s} 11661-012-1270-\mathrm{x}$

15. Fernandes FAP, Heck SC, Pereira RG, Lombardi Neto A, Totten GE, Casteletti LC. Wear of plasma nitrided and nitrocarburized AISI 316L austenitic stainless steel. JAMME. 2010;40(2):175179.

16. Rutherford KL, Hutchings IM. Theory and Application of a Micro-Scale Abrasive Wear Test. Journal of Testing and Evaluation. 1997;25(2):250-260. DOI: 10.1520/JTE11487J

17. Rutherford KL, Hutchings IM. A micro-abrasive wear test, with particular application to coated systems. Surface and Coatings Technology. 1996;79(1-3):231-239.

18. Bale CW, Chartrand P, Degterov SA, Eriksson G, Hack K, Ben Mahfoud R, et al. FactSage Thermochemical Software and Databases. Calphad. 2002;26(2):189-228.

19. American Petroleum Institute. Specification for line pipe. ANSI/API Specification 5L. Washington: American Petroleum Institute; 2008.
20. Araki T, Kozasu I, Tankechi H, Shibata K, Enomoto M, Tamehiro $\mathrm{H}$, eds. Atlas for Bainitic microstructures. Volume 1. Tokio: ISIJ; 1992.

21. Krauss G, Thompson SW. Ferritic Microstructures in Continously Cooled Low and Ultralow-carbon Steels. ISIJ International. 1995;35(8):937-945.

22. Bhadeshia HKDH. Bainite in Steels. $2^{\text {nd }}$ ed. London: Institute of Materials; 2001.

23. Lee $\mathrm{CH}$, Bhadeshia HKDH, Lee HC. Effect of plastic deformation on the formation of acicular ferrite. Materials Science and Engineering: A. 2003;360(1-2):249-257.

24. Babu SS, Bhadeshia HKDH. A direct study of grain boundary allotriomorphic ferrite crystallography. Materials Science and Engineering: A. 1991;142(2):209-219.

25. Itman Filho A, Cardoso KR, Kestenbach HY. Quantitative study of carbonitride precipitation in niobium and titanium microalloyed hot strip steel. Materials Science and Technology. 1997;13(1):49-55.

26. Honeycombe RWK, Bhadeshia HKDH. Steels: Microstructure and Properties. London: Elsevier; 2006. 360 p.

27. Porter DA, Easterling KE, Sherif M. Phase Transformations in Metals and Alloys. $3^{\text {rd }}$ ed. London: CRC Press; 2009.520 p.

28. Sundström A, Rendón J, Olsson M. Wear behaviour of some low alloyed steels under combined impact/abrasion contact conditions. Wear. 2001;250(1-12):744-754. 